\title{
Procurement process and financial performance: a systematic literature review
}

Mônica Georginoํ․ Federal University of São Carlos, São Carlos, Brazil. Department of Industrial Engineering.

Rosane Lucia Chicarelli Alcantara², Federal University of São Carlos, São Carlos, Brazil. Department of Industrial Engineering.

Andrei Aparecido de Albuquerque ${ }^{3}$, Federal University of São Carlos, São Carlos, Brazil. Department of Industrial Engineering.

Objetivo - O objetivo deste estudo foi identificar os elementos e atividades do processo de Compras que podem influenciar o desempenho financeiro de uma empresa.

Metodologia - Através da revisão sistemática da literatura (SLR) foi possível identificar os elementos e atividades do processo de compras e os indicadores financeiros.

Resultados - Foram identificados doze elementos (com destaque para: Tecnologia da informação e informação compartilhada e comunicação) e oito atividades do processo de Compras (com destaque para: gestão de relacionamento com fornecedor e redução de custos), que contribuem para o desempenho financeiro da empresa, principalmente nos indicadores financeiros Lucro e ROI.

Originalidade/valor - Esta pesquisa apresenta uma visão geral e consolidada da literatura sobre a relação atual entre o processo de Compras e o desempenho financeiro.

Palavras-chave: Compras. Desempenho Financeiro. Revisão Sistemática da Literatura. Elementos. Atividades.

\section{ABSTRACT}

Purpose - The aim of this study was to identify the elements and practices under the responsibility of the Procurement process that can influence the financial performance of a company.

Design/methodology/approach - A Systematic Literature Review (SLR) was conducted to identify the elements and practices from the Procurement process and financial indicators.

Findings - Twelve elements were identified (focusing on: Information technology and shared information and communications) and eight practices in the procurement process (focusing on: supplier relationship management and cost reduction), which contributes to the company's financial performance, mainly on the Profit and ROI financial indicators.

Originality/value - This study presents an overview, a consolidated view of the literature on the current relationship between the procurement process and financial performance.

Keywords - Procurement. Financial Performance. Systematic Literature Review. Elements. Practices.

1. Rua Luiz Razera, 22. Apto 12. Piracicaba (SP). CEP: 13.417-530, monicageorgino@gmail.com; https://orcid.org/0000-0002-4062-3216; 2. rosane@dep.ufscar.br, http://orcid.org/0000-0002-7018-5456; 3. andrei@dep.ufscar.br, https://orcid.org/0000-0002-2819-9993. GEORGINO, M.; ALCANTARA, R.L.C.; ALBUQUERQUE, A.A. Procurement process and financial performance: a systematic literature review. GEPROS. Gestão da Produção, Operações e Sistemas, v.16, n 3, p. 69 - 98, 2021.

DOI: $\underline{\text { http://dx.doi.org/10.15675/gepros.v16i3.2770 }}$ 


\section{INTRODUCTION}

There is a relatively large volume of studies in the literature concerned with Supply Chain Management (SCM) and the procurement process regarding company performance. For instance, Saranga \& Moser (2010) point out that many organizations have been quite efficient in contributing results by following the procurement process for corporate financial performance, highlighting the Earnings Before Interest, Taxes, Depreciation and Amortization (EBITDA) financial indicator.

From this perspective, Chen et al. (2004) concluded that there is a strong relationship between the Strategic procurement process, supply management, customer responsiveness and the financial performance of the buying firm. In addition, Pollice and Fleury (2011) conclude that the procurement process can contribute significantly to cash generation, asset management, indirect materials/services management and product development with suppliers to increase the volume of business, thus contributing to a company's financial results.

Due to businesses constantly under pressure to reduce costs, facing strong global competition, and focusing on the development of new products, customer satisfaction and instability in political, economic and environmental spheres (for example, the Mariana dam disaster in 2015, impeachment in 2016 and the truck drivers' strike in 2018), the challenge for companies is to deal with the complexity of supply chains, manage and mitigate operational risks to achieve increasingly competitive and positive results for their shareholders. Another reason that justifies this research is the fact that the studies published so far are mostly specific to one or another financial indicator, practice or element to which the procurement process contributes. In the bibliographical review carried out, few studies were identified that discuss corporate financial indicators in a consolidated way and how the procurement process contributes to each one of them; the study that comes closest to this approach is by Ellram and Liu (2002), published nearly 20 years ago.

Thus, the present work is driven by the objective of updating and consolidating theoretical studies that refer to a better understanding of the relationship between the procurement and Financial process. At the end of this work, the elements and practices of the procurement process that impact the financial performance of a company were identified.

In this research, the term procurement was used even some articles and older researchers use the term Purchasing because Procurement includes more than purchasing or 
negotiation, as: supplier relationship management, relationship with the stakeholders and internal customers, contract management, for instance.

The article has four sections, in which the first is the introduction. The second section presents the Systematic Literature Review (SLR) methodology; the third contextualizes the main themes of this research and presents the results of the SLR and, in the last section, the final considerations of the research are described.

\section{THEORETICAL FOUNDATION}

This topic will address the procurement process in the SCM and the main financial indicators from company to company.

\subsection{The Procurement process: the main fundamentals}

According to Ellram and Birou (1995), the procurement process plays a critical role in business due to the knowledge of solving conflicts and problems between internal suppliers and customers. Additionally, The Chartered Institute of Procurement and Supply (2021) defines Procurement as "buying the goods and services that enable an organisation to operate in a profitable and ethical manner".

There has been in a debate in the literature for some time now that the procurement process plays a role of greater integration with stronger cross-functional relations and that involvement from top management is necessary, that is, that the procurement process cannot be managed in isolation (KRALJIC, 1983). Carr and Smeltzer (1997) state that the purpose of the Strategic procurement function is to support a company's effort to achieve its long-term goals.

According to Brum (2018), the procurement process has to be able to not only interact, but also integrate a company's Supply Chain in order to monitor its dynamics and convert all the intelligence gained from this management into actions that generate value for the organization. The author defines that the procurement process is responsible for:

- Fully planning acquisitions based on the understanding of short, medium and long term demands and the effect on inventories. 
- Budgeting for the acquisition not only with an understanding of its technical specifications, but also with the spending targets, delivery time and inventory rules established.

- Analyzing and negotiating the quotes received involving impacted areas.

- Acquiring the goods or service and, finally, administering the contracts using predefined parameters.

Therefore, the procurement process needs to recognize and explore its position in view of a more strategic role in companies, as it integrates the supplier's capacity (which impacts internal performance such as manufacturing cost, quality and delivery) and external performance (such as time to introduce a new product and responsiveness to customization). Thus, the procurement process has the ability to solve problems at an operational and strategic level, in which Procurement issues are as important as those in the marketing, finance, accounting and operational areas for the company's competitive success (CARTER; NARASIMHAN, 1996; DAS; NARASIMHAN, 2000). The quality of materials and services purchased impacts the quality of the finished product and, consequently, customer satisfaction and company revenue (NOVACK; SIMCO, 1991). Additionally, with the flow of products and information between buyer and supplier, Procurement communicates to suppliers about changes in market demand which allows the company and its supply chain to be sensitive to changes (CHIANG et al., 2012).

In a study carried out by KPMG (2012), organizations with a more mature procurement process have better prices, greater business flexibility, greater spending leverage and, as a result, have a significant competitive advantage over their peers. Not having this maturity, the procurement process is only intended to review and negotiate contracts, that is, practices that are more tactical rather than strategic. Adding to this, Van Weele and Rietveld (2000) establish the six-staged procurement developmental model for the procurement process:

- Stage 1: Transaction Orientation. Having no procurement strategy, the main task of the procurement process is to find appropriate suppliers and ensure that the plant does not run out of raw materials and supplied components; there is no explicit procurement strategy and acquisitions are predominantly carried out by the users themselves; there is little knowledge of what exactly the 
company's total purchase expense is; management is based on complaints; there is a task-oriented team.

- Stage 2: Commercial Orientation. This focuses on the lowest unit price; striving for the lowest unit cost requires some independence from functions such as product development, engineering, and manufacturing; specialist buyers are organized around different product groups focused on negotiating and contracting "good deals"; the culture is that of playing hard negotiations with many suppliers; cost savings are used as a prime performance indicator to assess the overall effectiveness of procurement.

- Stage 3: Co-ordinated Procurement. At this stage, the procurement process has a central department with specific policies and systems; there is some kind of strategy formulation, aimed at capturing the benefits from internal coordination and synergy (such as centralizing the company's procurement); apart from price and costs, the procurement process is seen as having an important influence on the quality level of purchased products; Supplier Relationship Management (SRM) begins; the culture is characterized by a great amount of attention to communication and the intention to cooperate more internally between business units; the procurement staff has a specific background and training, such as analytical skills.

- Stage 4: Internal integration cross-functional procurement. This aims to reduce the total systems cost and not just the unit cost; key suppliers and longterm partnership are pillars in this phase; procurement is becoming more process oriented, trying to organize the procurement function around internal customers; the strategic importance of the procurement function is fully recognised; information systems are integrated with other areas; procurement performance measurement is done in the form of internal customer satisfaction surveys and benchmarking; the skills required are team-building abilities, strong communication and a long-term vision of the company.

- Stage 5: External integration. In this stage, procurement is characterized by outsourcing analyses, product development and pre-production planning; some processes are simplified, such as using systems contracting, procurement cards, electronic businesses, catalogs; integration with other areas of the company and 
suppliers is greater at this stage to enable integrated supply chain (SC) management; important skills are knowledge of Total Cost of Ownership (TCO) principles, strategic SC management, and general managerial and leadership skills; information systems are not only integrated internally but also with those of the partner suppliers.

- Stage 6: Value chain orientation. The most important recognition for procurement is that it delivers value to the end customer; suppliers are consistently challenged to support their product/market strategies and actively participate in product development and process improvement; the goal in this phase is to design the most efficient and effective value chain possible to serve the end- customer.

\subsection{Financial performance: the main fundamentals}

According to Drucker (2001), an institution exists to fulfill a specific purpose and mission, for a commercial company this means fulfilling an economic performance. A company creates value when the company's business generates a result above the remuneration required by creditors and shareholders, that is, when the return on invested capital exceeds the contracted cost and its financing (ASSAF NETO; LIMA, 2009). Thus, it is essential to manage the company's resources in order to maintain financial and economic health in order to achieve its established goals.

According to Assaf Neto (2014), financial administration is a theoretical and practical field of study that essentially aims to ensure a better and more efficient business process for raising and allocating capital resources. In this context, financial administration is involved both with the problem of scarce resources and with the operational reality and financial management practice in companies, assuming a broader definition. It is in this context that financial, operational and management decisions manage resources to maintain a company's financial and economic health in order to achieve its goals. In addition, identifying the factors that interfere with the financial performance of organizations is interesting for shareholders, who invest their capital, consumers, who want quality and good prices, and the government, due to its collections (CAPOBIANCO et al., 2012).

To measure and diagnose this company's financial and economic health, financial performance indices are analyzed to assess the company's overall performance and make 
decisions about its competitiveness and market growth, as well as comparing the performance of various companies. These indicators are available in the companies' financial reports and can be easily analyzed. Table 1 presents the main financial performance indicators.

Table 1: Financial performance indicators

\section{Financial performance indicators}

EVA (Economic Value Added)

Cash flow

Profit

Earnings before interest, Taxes,

Depreciation and Amortization (EBITDA)

Market share

Average payment period

Return on Assets (ROA)

Return on equity (ROE)

Return on investment (ROI)

\section{Definition}

Profit calculated after deducting all expenses and the opportunity cost of equity

Measuring the difference between cash receipts and expenses demonstrates the company's ability to pay

Results of company operations

Earnings before interest, income tax and social contribution, depreciation and amortization. Measures the ability to generate cash resources exclusively from its practice

Market share in which the company operates

Average time (months or days) that the company will pay for its suppliers for purchases

Return produced by the total investments made by a company in its assets

Return on resources invested in the company by its owners

Return produced by the total resources invested by shareholders and creditors

Source: authors' own work, based on Assaf Neto (2014).

\section{METHODOLOGICAL PROCEDURES}

According to Saunders and Rojon (2011), the literature review has to provide the context and theoretical framework to evaluate the most relevant and significant research to the studied topic. To reinforce this, Rowley and Slack (2004) state that a literature review distills the existing literature in a subject field, that is, it summarizes the state of the art based on previous and recent works. As some activities in the SLR process are repetitive and require discipline and systematic practice by the researcher, the information must be organized so that the SLR provides the expected results, is replicable, and allows that all the information can be packed (HERNANDES et al., 2012).

Thus, in the next parts in this section, the complete process of searching and analyzing the existing literature will be described: the keywords used, the search bases and the selection of articles. 


\subsection{Systematic literature review}

The methodology constituted by Tranfield et al. (2003) was adopted in this research. This methodology comprises three stages: planning, conducting and disseminating the SLR. Table 2 presents the steps used in this research at each stage.

Table 2: Proposal for structuring the Systematic Literature Review.

STEPS
Stage I - Planning the Systematic Literature Review
Preparation of a proposal for a review
Development of a review protocol
Stage II - Conducting the Systematic Literature Review
Selection and search of studies
Study quality assessment
Data extraction and monitoring process
Data synthesis
Stage III - Reporting and Disseminating Systematic Literature Review
Report and recommendations
Source: adapted from Tranfield et al. (2003, p. 214).

\subsubsection{Planning the systematic literature review}

To contribute to the research and structure of the SLR, a conceptual map was prepared aiming to outline the territory to be studied and recognize the relationship between the three concepts identified in the central theme of the research: Procurement, Supply Chain Management (SCM) and Financial Indicators. The purpose of the concept map is to support the researcher to develop their understanding of the subject, such as: identifying the search terms of the literature review, clarifying the structure of the literature review in preparation for review writing, understanding the theory, concepts and relationship between them (ROWLEY; SLACK, 2004).

In addition, Torraco (2016) stated that visual representations of the main ideas and conceptual relationships in the research enhance the reader's understanding of the author's critical analysis of the literature. The concepts to be analyzed in the SLR are shown in Figure 1. 
Figure 1: Conceptual map of the research theme and its intersections.

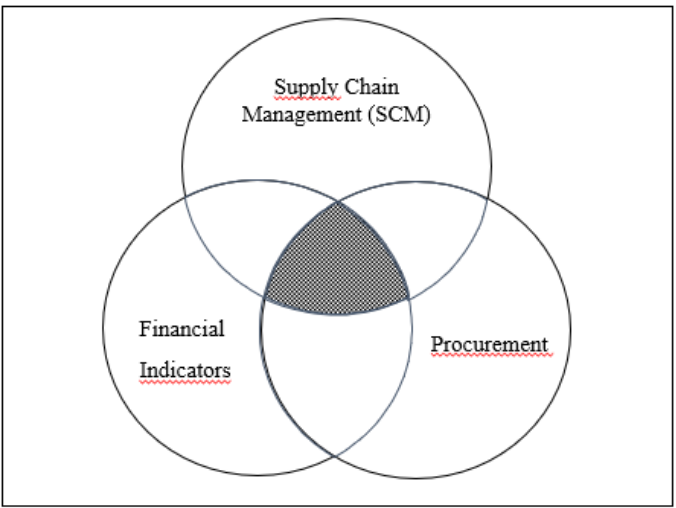

Source: authors' own work.

To ensure that the literature review identified the works already published with the theme of this research, a research protocol was designed aiming to follow a search plan, detailed in Table 3.

Table 3: Research protocol

\section{STEPS}

1. Access to international databases: Web of Science and Scopus.

2. Access to national databases: Scielo.

3. Access to the Brazilian Digital Library of Theses and Dissertations (BDTD in Portuguese).

4. Access to the proceedings of the main events in Production Engineering and Administration: National Meeting of Production Engineering (ENEGEP), Production Engineering Symposium (SIMPEP),

International Production, Logistics and Operations Management Symposium (SIMPOI) and Meeting of the National Association of Graduate Studies and Research in Administration (ENANPAD).

5. Access to the proceedings of the main events in the area of Finance: Brazilian Finance Meeting.

Source: authors’ own work.

According to Aghaei Chadegani et al. (2013), the Web of Science and Scopus databases are databases that allow for searching and classifying the results by established parameters (such as: author, subjects, journals, year of publication, among others) and the publications provided by these two databases are active journals, therefore they present current and relevant publications, in addition to being the most extensive academic databases. The choice of Scielo, BDTD and the proceedings of the Production Engineering, Administration and Finance area was to cover searches at the national level. 


\subsubsection{Conducting the systematic literature review}

Identification of the keywords, search instruments, reading and complete analysis of the documents resulting from the searches was conducted as shown in Table 4.

Table 4: Conducting the Systematic Literature Review.

\begin{tabular}{|c|c|}
\hline STAGE 2 & DETAILS \\
\hline \multirow{4}{*}{ Identification of studies } & Identification of constructs and keywords (Table 5) \\
\hline & Identification of Search instruments (Table 6) \\
\hline & Perform searches in selected databases \\
\hline & Identify Search period: $2008-2021$ \\
\hline \multirow{3}{*}{ Selection of studies } & 1st selection: article and accessibility to research \\
\hline & 2nd selection: reading title and abstract \\
\hline & 3rd selection: reading introduction and conclusion \\
\hline $\begin{array}{l}\text { Data extraction and data synthesis } \\
\text { process }\end{array}$ & $\begin{array}{l}\text { Reading full article and content analysis to identify the contribution and } \\
\text { relevant information for the research }\end{array}$ \\
\hline Monitoring process of new articles & Alerts in search bases with keywords and search tools created \\
\hline
\end{tabular}

Source: authors' own work.

The keywords and search terms were identified from the conceptual map (Figure 1) and used both in searches in national and international databases, therefore terms in Portuguese and English were mapped at this stage.

For each construct, a list of keywords was identified to reach the three areas of interest in this research: Procurement, SCM and Financial Indicators. As a way to validate this list of keywords, tests were performed to define the final list. Table 5 shows the terms searched.

Table 5: Constructs and keywords of the research.

\begin{tabular}{l|ll}
\multicolumn{1}{c|}{ CONSTRUCTS } & \multicolumn{1}{c}{ KEYWORDS } \\
\hline Procurement & -Compras & \multicolumn{1}{c}{-Procurement } \\
Supply Chain Management & -Purchasing \\
Financial indicators & $\begin{array}{l}\text {-Gestão da cadeia de } \\
\text { suprimentos }\end{array}$ & -Supply Chain Management \\
& -Índice & -Indicator \\
& -Margem de lucro & -Profit margin \\
& -Prazo de pagamento & -Payment term \\
& -Economia & -Saving \\
& -Desempenho & -Performance \\
& -Desempenho financeiro & -Financial performance \\
& -Capital giro & -Working capital \\
& -Ciclo caixa & -Cash cycle \\
& -Fluxo caixa & -Cash flow \\
& -Redução de custo & -Cost reduction \\
Financial indicators & -Rotatividade de ativos & -Asset turnover \\
& -Gestão ativos & -Asset management
\end{tabular}




$\begin{array}{ll}\text {-Estoque } & \text {-Stock } \\ \text {-Gestão investimento } & \text {-Warehouse } \\ \text {-ROA } & \text {-Asset investment } \\ \text {-ROACE } & \text {-Index } \\ \text {-ROCE } & \\ \text {-ROE } & \\ \text {-ROI } & \\ \text {-EBITDA } & \\ \text {-EVA } & \\ \text {-Financ* } & \end{array}$

Source: authors'own work.

After identifying the keywords, searches were performed in the bases chosen in the research protocol (Table 2), according to the search terms in Table 6. The search instruments were used in the "title" field of the databases, and the filter used was the date of publication of the articles. Search tests were also applied to determine the period of collection of published articles, and this was determined from January 2008 to March 2021, due to the relevance of the topic in recent years and also because the articles published are concentrated in this period. Alerts were created on search platforms to capture new studies published during the research, making it as up-to-date as possible.

Table 6: Searched bases and terms used.

\section{BASE}

- Scielo

- Brazilian Digital Library of Theses and Dissertations (BDTD in Portuguese)

- Scopus

- Web of Science

- ENANPAD

- SIMPEP

- Brazilian Finance

Meeting

- Brazilian Finance

Meeting

Source: authors' own work.

\section{SEARCH TERMS}

compras OR "gestão da cadeia de suprimentos" AND (índice OR desempenho OR indicador OR ROI OR "fluxo de caixa" OR Ebitda OR EVA OR ROA OR ROE OR ROACE OR estoque OR "capital de giro" OR financ* OR "prazo de pagamento" OR ROCE OR "desempenho financeiro" OR "gestão de ativos" OR "gestão de investimento" OR "margem de lucro" OR "rotatividade de ativos" OR "ciclo de caixa" OR "redução de custo" OR economia)

procurement OR "Supply chain management" OR "purchasing" AND (index OR performance OR indicator OR ROI OR "Cash flow" OR Ebitda OR EVA OR ROA OR ROE OR ROACE OR warehouse OR "working capital" OR financ* OR "payment term" OR ROCE OR "financial performance" OR "asset management" OR "asset investment" OR "profit margin" OR "asset turnover" OR "cash cycle" OR stock OR "cost reduction" OR saving)

compras

suprimentos

compras OR suprimentos 


\subsubsection{Disseminating the systematic literature review}

After searching each database, cases of duplicate articles were checked to remove them from the amount recovered. Regarding the selection of studies, three phases were adopted: first, availability, type of document (books were excluded and journals of low quality as well). Second, the title and abstract of each article was read to identify which papers would bring relevant and meaningful information to the research, focusing on: procurement and financial indicators, the relationship between the procurement process and the area of finance, studies that explored the procurement process as a contributor to the financial performance or even studies that correlated some element or activity of the procurement process with the company's financial performance. Therefore, at this stage, many articles were eliminated because they dealt with topics that would not add to the research, such as: green supply chain management, supply chain management in healthcare, logistical services in supply chain management, financing of suppliers in the supply chain, corruption in bidding and/or public procurement, books and articles from journals of little relevance.

Third, the introduction and conclusion were read, and those that did not add or did not allow the identification of depth, definition or explanation to the same criteria evaluated when reading the title and abstract were removed.

Fourth, the articles were thoroughly read in full, thus 14 articles were identified as critical to the research question and, finally, another ten articles were incorporated into the SLR while reading the selected articles, as some had references that after reading in full proved to be valuable for the review because they are relevant to the research topic. This technique is called a "backward search" and its purpose is to collect articles from reading articles that appeared in the SLR. According to Vom Brocke et al. (2015), this inclusion is essential to compose the review when the keyword search did not identify it, and because it makes the SLR robust and helps researchers to have confidence in finishing the search.

These 24 articles comprised the SLR of this research, contributing to the knowledge and creation of a better understanding of how the procurement process, through its elements and practices, impacts the company's financial performance. Conducting the SLR, as well as following the steps and the number of articles that resulted from each of the steps, is illustrated in Figure 2. 
Figure 2: Conducting the Systematic Literature Review.

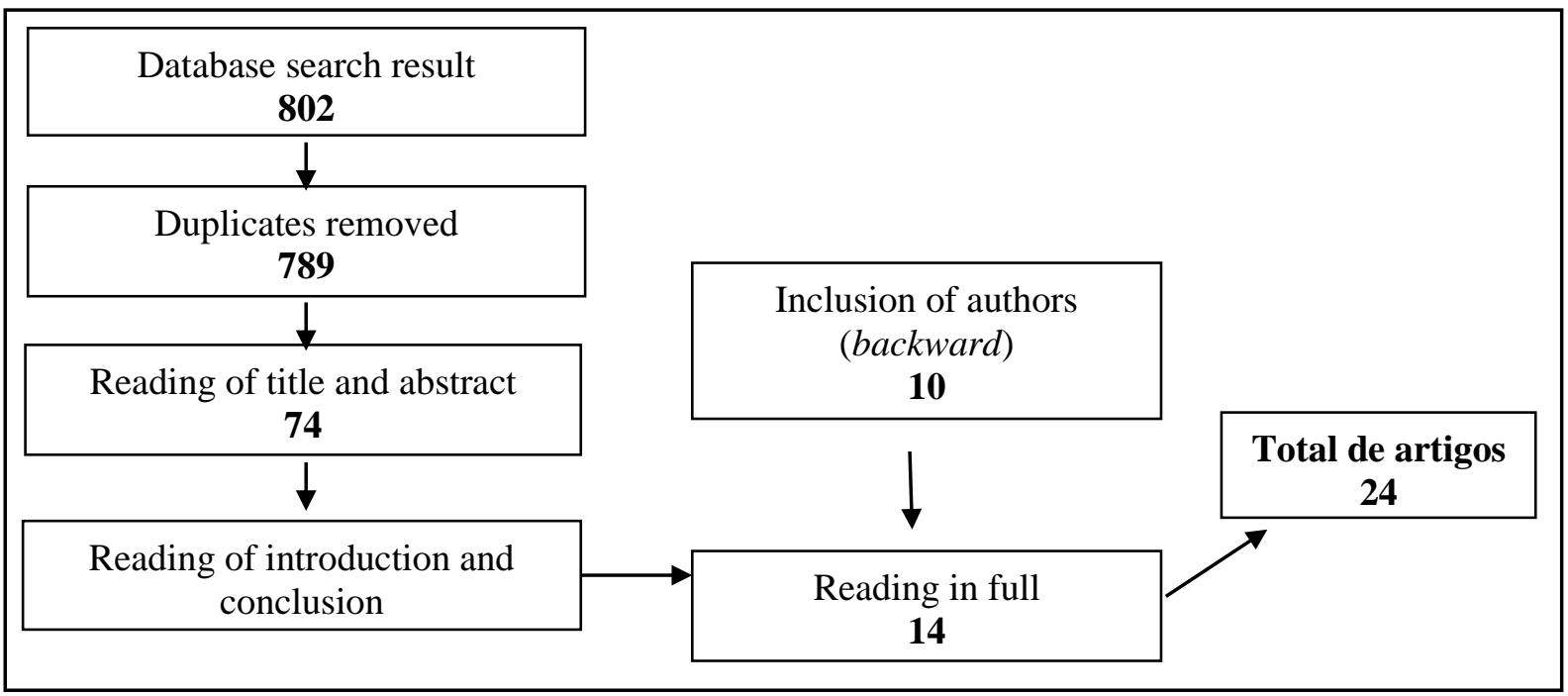

Source: authors' own work.

\section{RESULTS AND DISCUSSIONS}

\subsection{The Procurement process and its elements}

Throughout the SLR, twelve elements were identified that were inserted throughout the whole procurement process and in its interface with partners and other business areas of the company, that is, elements that bring the bias that the procurement process does not exclusively have the decision-making power or totality of the management of these elements and which, to a certain extent, contributes to the company's financial performance. They are as follows: collaboration, senior management commitment, trust, procurement structure, risk management, talent management, sustainable management, shared information and communication, innovation, lead time, long-term planning and information technology.

The authors of the 24 final SLR articles used the following terms: constructs, drivers, efforts, factors, indicators, items, key elements, management axis, mechanisms, practices, process, variable. Having said that, from an interpretive translation, the word "elements" was defined. These elements are presented in Table 7 and will be described below. 
Table 7: Elements present in the procurement process that impact the company's financial performance.

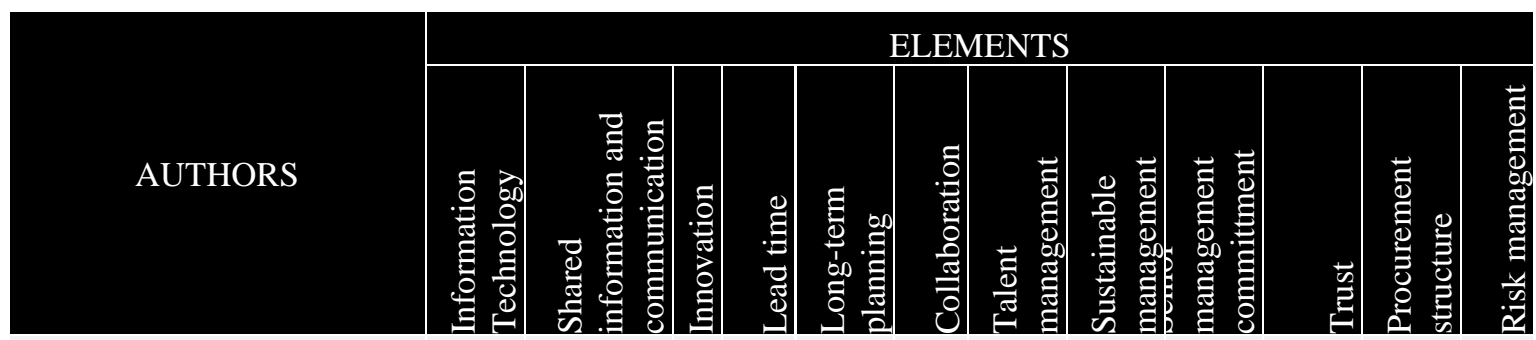

Andrade and Marçola (2009)

Cao and Zhang (2011)

Carr and Pearson (1999)

Carr and Pearson (2002)

Chen and Kitsis (2017)

Chen, Paulraj , Lado (2004)

Cho et al. (2012)

Clayton (2000)

Ellram and Liu (2002)

Foerstl et al. (2013)

Hahn and Kuhn (2012)

Kim, Suresh, KocabasogluHillmer (2015)

Kumar, Singh, Shankar (2015)

Lai, Wong and Lam (2015)

Mondini et al. (2015)

Okongwu, Brulhart and

Moncef (2015)

Ou et al. (2010)

Paulraj, Chen and Blome (2017)

Peng et al. (2016)

Pradabwong et al. (2017)

Saranga and Moser (2010)

Terpend et al. (2008)

Ubeda, Alsua and Carrasco (2015)

Total number of citations

Source: authors' own work.

More structurally, using information technology such as the Internet, Intranet, software application packages and support systems can be applied to facilitate the flow between SC members (FAWCETT et al., 2009; PENG et al., 2016), whether concerning information, processes or management. Thus, the operational work is reduced by automating some operations: minimizing manual errors, ensuring governance, standardization and process 
agility. Specifically exploring agility, in corporate environments, digitization in Procurement (and also the digital transformation in Procurement 4.0) has been discussed recently, which is based on the discussion of Information Technology in procurement processes to gain agility in fulfilling purchase negotiations.

Shared information and communication contribute to practices of acquisition, processing, use and transfer of information from members involved in the process, again reinforcing the governance of the procurement processes and ensuring a holistic view of the whole process and also contributing to risk mitigation as soon as any adversity is shared with other interested parties. According to Chen and Kitsis (2017), companies manage SC sustainability challenges through various initiatives and practices, including communication, collaboration, information sharing, building trust and risk management.

According to Foerstl et al. (2013), according to the marketing and product development functions, the success of an organization's strategy in general can be defined in terms of quality improvement and product innovation, in which the procurement process plays an important role, as wrongly selecting suppliers and wrong incentives to those suppliers can result in detrimental effects on performance in terms of quality and innovation.

Regarding the adequate lead time for the procurement process, it is understood that punctuality in fulfilling Procurement requisitions is an important element because it verifies how efficient the (internal) procurement process is to attend the Procurement requisitions issued by the operation, which will impact the final delivery of the product to the customer (ANDRADE; MARÇOLA, 2009). As an example, one of the main performance indicators KPI (Key Performance Intelligence) of Procurement is the term of service for Procurement requisitions, buyers are measured in how many days they can complete the negotiation from the approval of the procurement requisition, depending on the type of negotiation (spot or contract), the type of scope (service or material), or the criticality of the scope that will be negotiated.

Long-term procurement planning is an element that needs to be aligned with the company's long-term plans and goals, whenever there is any adjustment made in the company, it somehow has to be deployed to the procurement process. For example, to support the acquisitions that the company needs for these long-term achievements, a new system needs to be acquired, the size of the Procurement staff needs to be optimized, focusing on some other element (such as talent management) or practices that will be analyzed shortly 
(such as cost management or contract management). The procurement process with a strategic orientation, aligned and converging with the company's general objectives, which emphasizes cooperation and maintenance among members, is more likely to obtain better economic performance compared to firms that do not adopt the strategic vision in the procurement process (CHEN et al., 2004; MONDINI et al., 2015).

According to Cao and Zhang (2011), SC collaboration occurs in process focus and relationship focus, with message transmissions and contact between all those involved in SC from suppliers to customers. These relationships include firms that should try to create a winwin situation. The result is a better advantage and firm performance. According to Fawcett et al. (2015), collaboration in SC is the ability to work across organizational boundaries to build and manage unique value-added processes. This element increases the ability of visibility among those involved, and as well as the shared information and communication, it ensures a holistic view of the whole process and contributes to risk mitigation.

In talent management, organizations should not only be concerned witha the recruitment and selection of these professionals, but also mainly with retaining talent, through development, compensation and training policies that can be conducted by internal and external experts (ABREU, 2016; FOERSTL et al., 2013). Currently, for example, it can be observed that companies have been using recognition resources (often not remunerated, such as a highlight on the company's Intranet or even on the company's Linkedin page) to prominent professionals, whether for some initiative or project, aiming to retain talent and encouraging other professionals to also participate.

Paulraj et al. (2017) argued that sustainable management of SC demonstrates that sustainable product design, process design, supply-side sustainability collaboration, and demand-side sustainability collaboration play a central role in enhancing a company's environmental and financial performance. This element can be highlighted in recent years, mainly in publicly traded companies, as Environmental, Social and Governance (ESG) is a theme that includes discussions on environmental, social and governance as analysis criteria, and not just using firms' main economic and financial indicators.

It can be observed that throughout the procurement process, senior management commitment provides sufficient resources and financial support to build a successful system and engage everyone involved. In addition, senior management support will ensure that SCM 
implementation has a high priority within the organization and that it will receive the necessary resources and attention (KUMAR et al., 2015).

Sharing sensitive strategic information depends on trust in the relationship. Trust among SCM members ensures that what has been agreed will be carried out (FAWCETT et al., 2015). According to Chen and Kitsis (2017), as trust among SCM members grows, that particular product or service becomes more difficult for competitors to copy.

Regarding the Procurement structure, Saranga and Moser (2010) argued that the number of buyers, the number of transactional buyers and the number of suppliers are performance drivers, as with a correct number of buyers, management will be carried out efficiently, and a lean supplier base will contribute to their management. Thus, it is interesting to understand with other companies (competitors or not), how benchmarking is, how the distribution of some data is (for example: annual expenditure per buyer, number of contracts per buyer, number of transactions per buyer, number of suppliers per buyer) to better adapt the productive capacity of the procurement structure. It should be remembered that information technology can contribute to this Procurement structure acquiring some solution or technology for buyers to optimize their day-to-day work.

Chen and Kitsis (2017) warned that risks can occur through government sanctions, environmental catastrophes and consumer boycotts, for example. This element has clearly been highlighted in recent years due to the Samarco mining Mariana dam disaster in Minas Gerais in November 2015, the truck drivers' strike in Brazil in May 2018, taxing Brazilian steel to the North American market throughout 2018 and 2019, and more recently, the COVID-19 pandemic. Quickly understanding how these risks impact the procurement process and its suppliers, managing to map quick solutions or how to be less impacted, is risk management.

\subsection{The Procurement process and its practices}

Together with the elements of the procurement process (presented in the previous subtopic), the existence of specific activities related to the procurement process was found throughout the SLR. In this study, procurement process practices are understood as those that are the responsibility of the procurement process, or that Procurement has greater decisionmaking power. Eight practices were identified, namely: SRM; cost reduction; demand 
management; analyzing the option to make, lease, outsource or buy; contract management; order management; Strategic Sourcing; and Total Cost of Ownership. These practices are presented in Table 8 and will be described below.

Table 8: Procurement responsibility practices that impact financial performance.
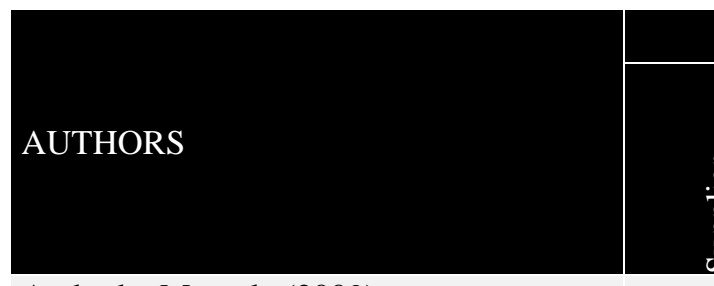

Andrade; Marçola (2009)

Cao; Zhang (2011)

Carr; Pearson (1999)

Carr; Pearson (2002)

Chen; Kitsis (2017)

Chen, Paulraj; Lado (2004)

Cho et al. (2012)

Clayton (2000)

Ellram; Liu (2002)

Francisco; Silva (2018)

Foerstl et al. (2013)

Hahn; Kuhn (2012)

Kim, Suresh; Kocabasoglu-Hillmer (2015)

Kumar, Singh; Shankar (2015)

Lai, Wong; Lam (2015)

Mondini et al. (2015)

Okongwu, Brulhart; Moncef (2015)

Ou et al. (2010)

Paulraj, Chen; Blome (2017)

Peng et al. (2016)

Pradabwong et al. (2017)

Saranga; Moser (2010)

Terpend et al. (2008)

Ubeda, Alsua; Carrasco (2015)

Total

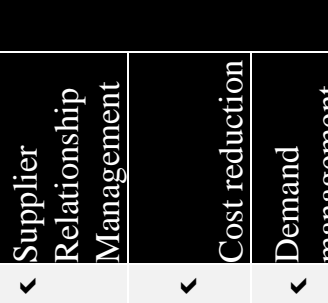

PRACTICES

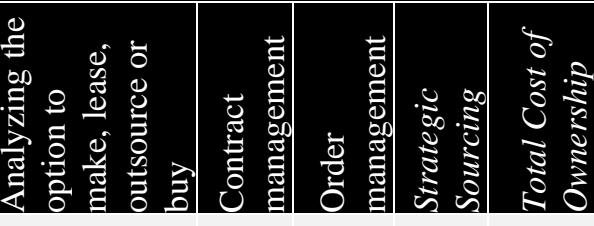

Source: authors' own work.

Supplier Relationship Management (SRM) was the most identified practice in the SLR. According to Lambert and Enz (2016), SRM is part of the SCM and SRM was previously called procurement (NOVACK; SIMCO, 1991; LAMBERT; COOPER, 2000; CROXTON et al., 2001). One of the functions of the procurement process is to establish contracts with suppliers to purchase materials and services (SLACK, 2002) and SRM comes from the structure of how these relationships with suppliers must be developed and 
maintained (LAMBERT, 2014). In an ideal scenario, suppliers should be considered as partners in the procurement process, in a win-win relationship, either by reducing costs or proposing process improvements.

Another activity identified during SRM was cost reduction, which can occur in different ways: negotiating prices of acquisitions carried out by Procurement, payment terms, discussion of scope to adjust to what is really necessary for the operation, exchanging raw material for a cheaper one, but one that maintains the quality, analyzing the internalization of a service, for example, instead of contracting with a supplier, negotiating consignment stock with a supplier, changing the type of transport (Cost insurance and Freight - CIF or Free on Board - FOB), drawing up a contract with the supplier (consolidating the volume) instead of making several purchases, among other examples. Clayton (2000) stated that a significant element of the cash flow is the supplier's payment terms. By negotiating good payment terms with suppliers, a company can create a positive cash flow (ELLRAM; LIU, 2002).

Demand management is defined as the volume of what material or service will be purchased to achieve the organization's goals. Strategic practices, such as demand forecasting and consumption analysis, can generate significant cost savings and improve financial performance (ÚBEDA et al., 2015). In an ideal scenario, there will be enough items in stock for the operation, as the more items in stock, the more financial resources were spent or committed, and that could have been used more beneficially in other corporate priorities. Or, if items are missing, it can affect production and a drop in sales. This practice is highly relevant, and in line with the other two elements: collaboration and shared information and communication.

Analyzing the option to make, lease, outsource or buy depends on a strategic model that extends the traditional cost analysis considering strategic, technological and financial factors. It is essential that the buyer understands the scope of the contract very well, having already analyzed the costs of the four options, whether with the options of suppliers or with the areas and stakeholders of the company. This framework, in conjunction with a cost analysis, can help companies make decisions to position them for sustained competitive success in the future (WELCH; NAYAK, 1992). According to Fill and Visser (2000), the decision to outsource part of an organization's activities is often the result of an initiative to obtain potential production cost efficiencies. According to Clayton (2000), the analysis of 
making, buying or outsourcing has to be carried out even before Procurement receives the procurement requisition.

A common strategy in the procurement process to mitigate supply risk is to enter into a contract with the supplier. Contract management exists precisely for buyers to monitor the progress of their contracts, such as maturity, demand consumption, performance and price adjustment. According to $\mathrm{Fu}$ (2015), the buyer can enter into a contract maintaining flexibility to adapt to changes in demand or price, or even negotiate several supply contracts to distribute and balance the acquisition risk.

Order management is responsible for organizing the response of processed orders, from receipt to delivery, responding to customer requests and minimizing the total cost $(\mathrm{CHO}$ et al., 2012). Note that this activity and the lead time element are very close and both are considered common performance indicators in procurement processes.

Strategic Sourcing is essential for companies that practice SC management principles and this practice aims to maximize the value of the product or service to the end customer, allowing it to generate shareholder value (TALLURI; NARASIMHAN, 2004; ANDERSON; KATZ, 1998) to help companies find competitive advantages (KIM et al., 2015) and make decisions based not only on cost, but also seeking opportunities that bring benefits, added value and long-term partnerships (PASQUALE, 2007). This activity is based on a methodology, which analyzes the category or hiring in question in great depth, analyzing the supplier market and the company's needs, focusing on studying the different strategies and defining which will be the best for the company. Strategic Sourcing is present in more mature procurement processes, using the model by Van Weele and Rietveld (2000) explored in Subtopic 2.1, it is a practice found in Stages 5 and 6.

In addition, Total Cost of Ownership (TCO) is one of the ways to reduce cost, as it considers the practices and costs of the supplier over the complete lifecycle of a product or service throughout its use and not just the acquisition value (ANDERSON; KATZ, 1998; ELLRAM ; LIU, 2002). In line with the practice of analyzing the option to make, lease, outsource or buy, for the buyer to analyze the TCO, it is essential to understand the scope and to have carried out discussions and analyses upstream and downstream of the SC for better decision-making. 


\subsection{Integration between the procurement process and financial indicators}

As seen in Section 4.2, SRM is an important activity in the procurement process, and is the most identified practice throughout the SLR. In an interesting study, Pohlen and Lambert (2001) developed the concept that SRM can impact the entire organization and reflect on the company's profit reports by lower inventories (procurement, in-process and finished inventories), better use and rationalization of assets (warehouse and plant) and better planning and investments.

In order to better present the SLR results, Table 9 was made, which shows the financial indicators impacted by the procurement process. There are 12 indicators in total: inventory cost; Economic Value Added (EVA); cash flow; profit; Earnings Before Interest and Taxes (EBIT); Earnings Before Interest, Taxes, Depreciation and Amortization (EBITDA); market share; average payment period; return on equity (ROE); return on investment (ROI); return on assets (ROA) and company value.

Table 9: Financial performance indicators impacted by the procurement process, identified in the SLR.

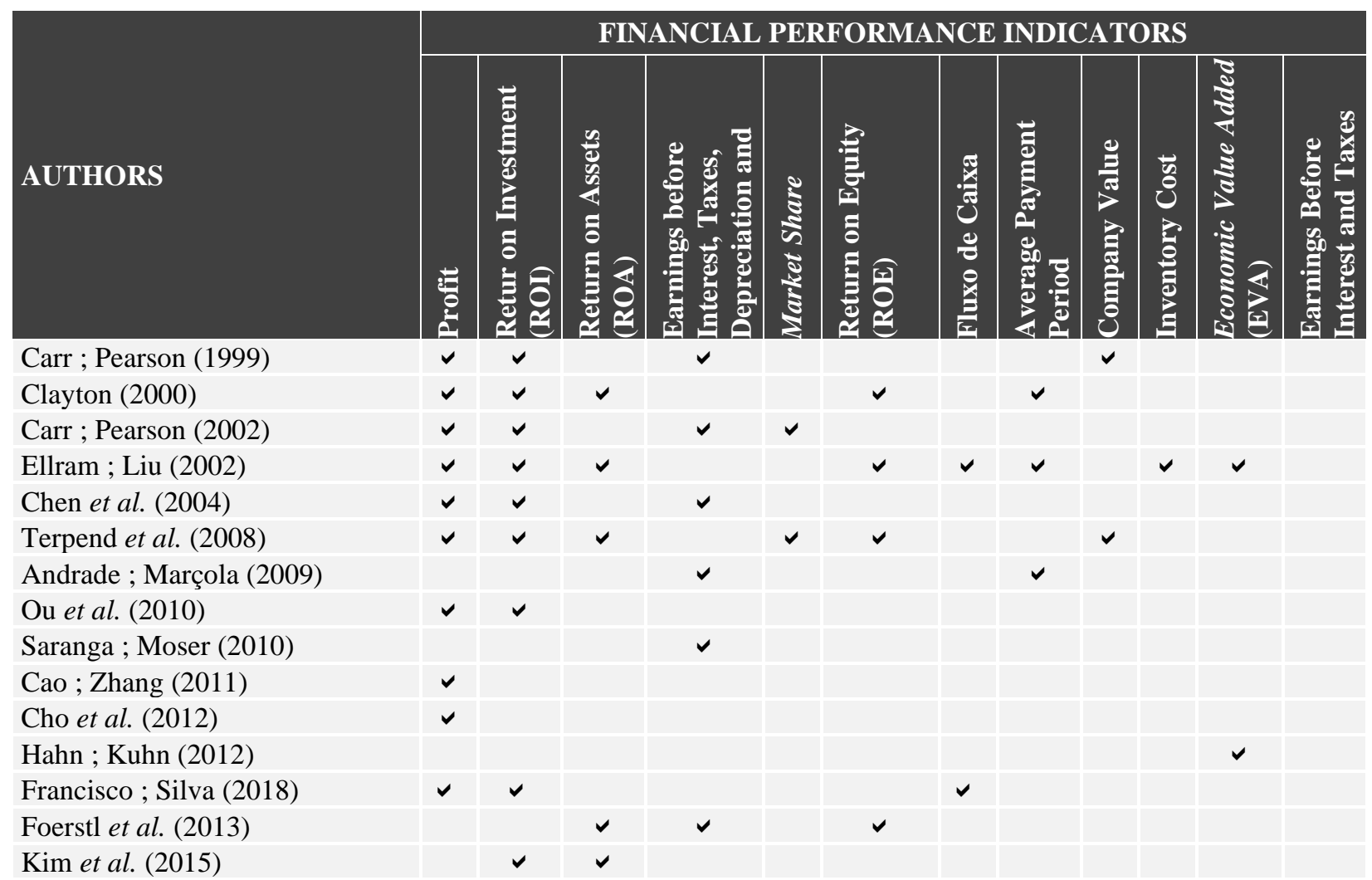


Kumar et al. (2015)

Lai et al. (2015)

Mondini et al. (2015)

Okongwu et al. (2015)

Úbeda et al. (2015)

Peng et al. (2016)

Chen ; Kitsis (2017)

Paulraj et al. (2017)

Pradabwong et al. (2017)

Total number of citations

Source: authors' own work.

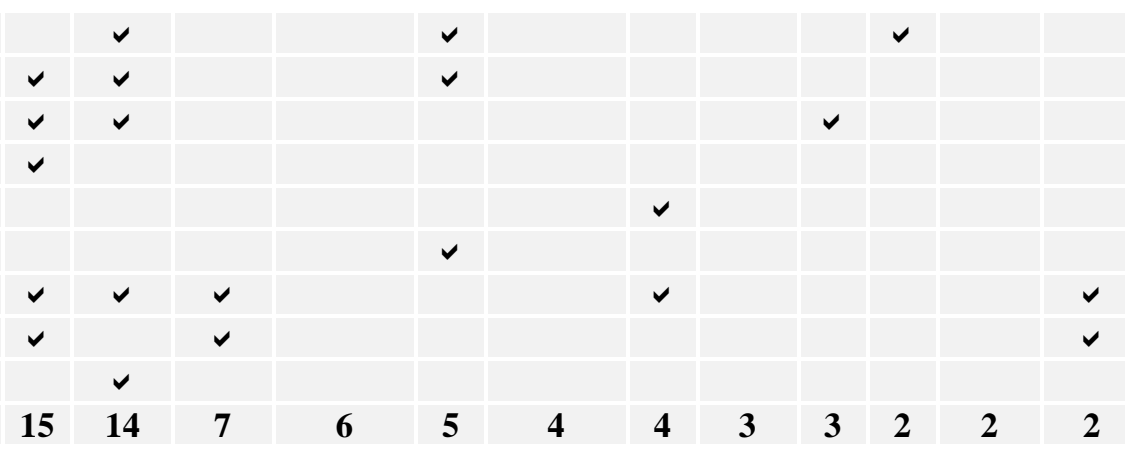

Throughout their work, these authors mentioned the impact of the procurement process on the company's financial performance, referring to some of these financial performance indicators.

In order to explore the relationship between the procurement process and the company's financial performance, this relationship based on the performance indicators most mentioned in the SLR will be highlighted: Profit, ROI, ROA, EBITDA and Market Share.

Ou et al. (2010) argued that a successful SCM improves a company's operational performance, which leads to greater customer satisfaction. Considering this, the company's market share can increase, thus improving ROI and gross profit ratios. Cho et al. (2012) also analyzed the relationship between the financial indicator and the procurement process, and reinforced that the level of relationship between buyer and supplier, the total cost of the service delivered, the quality and service level of suppliers contribute to the company's ROI.

Ellram and Liu (2002) identified three resources that the procurement process performs and directly contributes to the company's profit and growth: service outsourcing, inventory management and payment terms.

Cho et al. (2012) also analyzed the relationship between the financial indicator and the procurement process and reinforced that the level of relationship between buyer and supplier, the total cost of the service delivered, the quality and service level of suppliers contribute to the company's ROI. Furthermore, more recently, in a study conducted by Kim et al. (2015), it was analyzed that Strategic Sourcing and e-procurement (information technology tool) have a positive impact on two financial indicators: ROA and ROI.

Saranga and Moser (2010) stated that the procurement structure, such as the number of strategic buyers and transactional buyers, and the number of suppliers impact EBITDA. 
According to Foerstl et al. (2013), ROA and EBITDA are positively impacted through talent management (training and talent development) and Procurement performance (direct costs, total acquisition costs, quality, payment terms and contribution to innovation).

From a managerial point of view, the content presented can guide the procurement manager to search for elements and practices, to be added to the procurement process, which can improve their impact on the company's financial performance. In addition, being aware that Return on Investment (ROI), Profit and Return on Assets (ROA) are the financial indicators most impacted by the procurement process, managers can simulate how different conditions of the procurement process and the negotiations will impact the company's financial result before the decision is taken.

Based on these results obtained by the SLR and presented throughout this article, Figure 3 was developed aiming to summarize the theoretical conclusions identified in this study. This figure shows the elements that must be present in the company's procurement process and the practices performed in this process that impact the company's financial performance (in descending order of cited authors), evaluated through the financial indicators presented.

Figure 3: Elements and practices of the procurement process and financial performance indicators impacted.

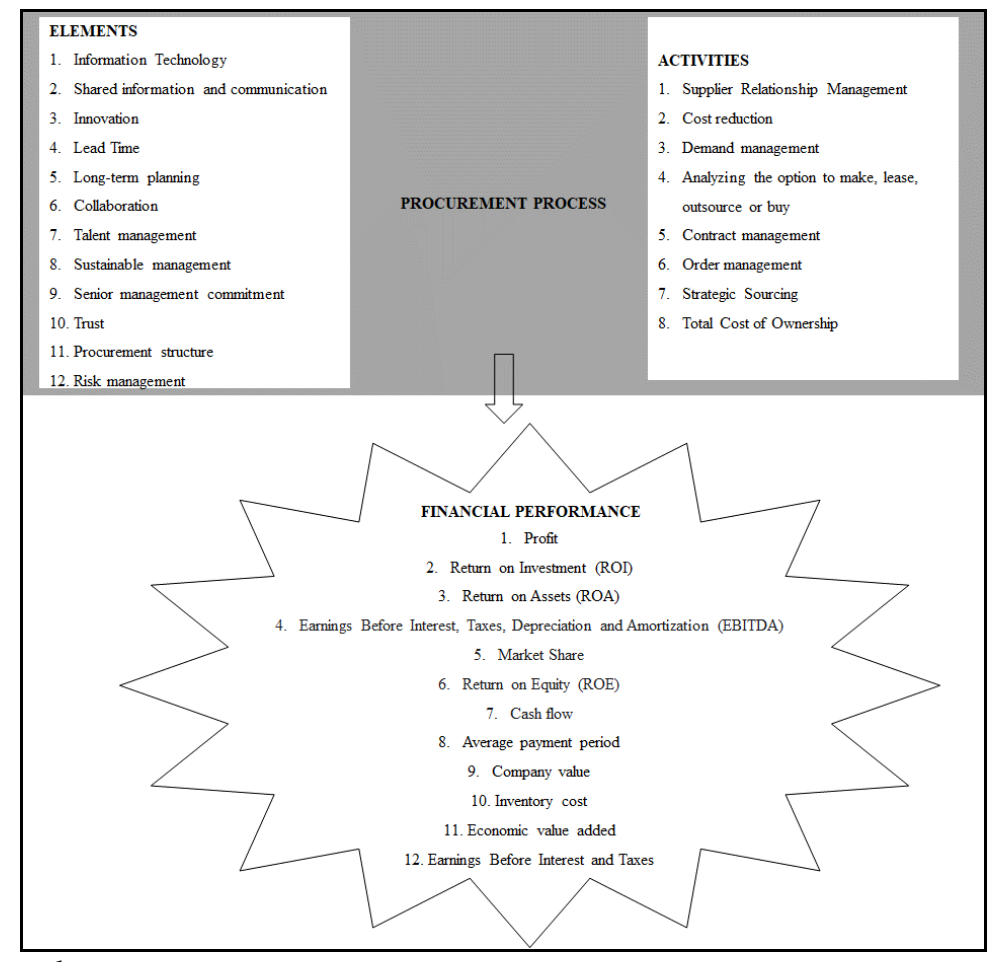

Source: Authors' own work. 


\section{CONCLUSION}

Based on the results obtained in the SLR carried out, this research helped to identify and systematize the main elements and activities of the procurement process, and the financial indicators impacted by this process. The most cited elements were information technology, shared information and communication, innovation and lead time. The activities were supplier relationship management, cost reduction and demand management. The most cited financial indicators were: profit, return on investment (ROI) and return on assets (ROA). The identification of these elements will allow Procurement professionals to act with focus and depth, aiming at improving the performance of the procurement process, and enhancing its impact on the company's financial performance.

Among the elements identified in the SLR, the most cited was information technology. The use of systems and software ensures the automation of some operations, reduces manual errors, ensures governance, standardization and agility in processes. The second most cited element was shared information and communication, which aims to use and transfer information from the members involved in the process. It contributes to ensure that policies and processes are clear and accessible to everyone involved, in addition to ensuring a holistic view of the whole process for all SC members, acting quickly on risks that may impact financial performance. It can also be inferred that these two elements complement each other as sharing information can occur via systems, in an agile and reliable way.

Third, innovation and lead time were the most mentioned element where the procurement process plays an important role on innovation to ensure selection and encouragement of the right suppliers to result in quality performance and innovation. Lead time, on the other hand, ensures punctuality in the fulfillment of Procurement requisitions, contributing to the final delivery period to the customer.

The most identified activity in the SLR was SRM. Suppliers should be considered as partners in the procurement process, in a win-win relationship, proposing process improvements. Second was the cost reduction that occurs in several ways: from negotiating prices and payment terms to discussing the scope, to adjust to what is really necessary for the operation or to enter into a contract with the supplier (consolidating the volume) instead of making multiple purchases on time. 
In third place was demand management, to have a balance in the stock so that there is no excess (which means that more financial resources have been spent or committed) or there is shortage (which can affect production and a drop in sales).

Moreover, these elements and practices highlighted in this final consideration are in line with the highest maturity levels highlighted in Van Weele and Rietveld (2000): eprocurement and electronic auction (as information technology), partner supplier (as SRM) and knowledge of TCO (for cost reduction as it presents a view of the total cost of ownership). Thus, contributing not only to the company's financial performance, but also to the procurement process itself, with greater maturity.

This study also highlights those financial indicators such as Profit, ROI and ROA (ELLRAM; LIU, 2002; OU et al., 2010; CHO et al., 2012; FOERSTL et al., 2013; KIM et al., 2015) are impacted by the procurement process. Therefore, the positive and direct relationship between the procurement process and the company's financial performance is clearly seen, whether through systems and software used in procurement to gain agility, transfer information throughout the procurement process, ensure stocks, relationship with suppliers, reduction in acquisition cost, among others explored in this work. Thus, from a managerial point of view, procurement managers can be guided in the search for elements and practices that can improve the impact on the company's financial performance.

It is believed that the contribution of this study may allow future work to advance in the analysis of the effects of the presence of elements and practices in the procurement process, summarized in Figure 2, on the observed financial indicators. In a more targeted way, this study may contribute to future research that seeks to identify how the elements and practices of the procurement process influences the financial performance of companies, both by the indicators observed here and by other professionals or academics.

Regarding the limitations of this research, it can first be said that this is a study directed at the procurement process, therefore other links of the SCM were not researched. Second, it is a theoretical study based on three academic databases (Web of Science, Scielo and Scopus) which, although they are among the main ones in the area, do not cover all the available databases. Based on these observations, it is suggested that future work can explore both other links in SCM and other databases of technical-scientific literature. On the other hand, future research can advance in empirical applications, taking advantage of the 
theoretical framework established here for practical observations in companies of the possible impact of the procurement process on their financial performance.

\section{References}

ABREU, A. Contribuições das práticas de recursos humanos na integração interna da gestão da cadeia de suprimentos. 2016. Tese (Doutorado em Engenharia de Produção) Universidade Federal de São Carlos, São Carlos, 2016. Disponível em: https://repositorio.ufscar.br/handle/ufscar/8727. Acesso em: 14 jun. 2017

AGHAEI CHADEGANI, A. et al. A comparison between two main academic literature collections: Web of Science and Scopus databases. Asian Social Science, v. 9, n. 5, p. 1826, 2013.

ANDERSON, M. G., KATZ, P. B. Strategic sourcing. The International Journal of Logistics Management, v. 9, n.1, p. 1-13, 1998.

ANDRADE, J. H.; MARÇOLA, J. A. Proposta de um conjunto de indicadores de desempenho para o processo de compras. In: SIMPÓSIO DE ENGENHARIA DE PRODUÇÃO, 16, 2009. Anais...XVI Simpep, Unesp, Bauru, São Paulo, 2009.

NETO, A.A. Finanças corporativas e valor. Atlas, 2003.

NETO, A. A.; LIMA, F. G. Curso de administração financeira. Atlas, 2009.

BRUM, V. Coluna liderança: Procurement de excelência: como obter resultados por meio de uma gestão de compras mais estratégica. O Papel: revista mensal de tecnologia em celulose e papel, v. 79, n. 2, p. 34-36, 2018. Disponível em: https://www.falconi.com/flcn_articles/procurement-de-excelencia-como-obter-resultadospor-meio-de-uma-gestao-de-Compras-mais-estrategica. Acesso em: 14 jun. 2017.

CAO, M.; ZHANG, Q. Supply chain collaboration: Impact on collaborative advantage and firm performance. Journal of operations management, v. 29, n. 3, p. 163-180, 2011.

CAPOBIANGO, R. P.; ABRANTES, L. A.; FERREIRA, M. A. M.; FARONI, W. Desempenho financeiro: um estudo com empresas de três diferentes setores. Revista De Ciências Humanas, v. 1, n.1., $2019 . \quad$ Recuperado de https://periodicos.ufv.br/RCH/article/view/3910. Acesso em: 14 jun. 2017.

CARR, A. S.; SMELTZER, L. R. An empirically based operational definition of strategic purchasing. European Journal of Purchasing and Supply Management, v. 3, n. 4, p. 199-207, 1997.

CARTER, J. R.; NARASIMHAN, R. Is purchasing really strategic? International Journal of Purchasing and Materials Management, v. 32, n. 4, p. 20-28, 1996.

CIPS. The Chartered Institute of Purchasing \& Supply. 2021. Disponível em: $<$ https://www.cips.org/cips-for-individuals/what-is-procurement/>. Acesso em: 29 jun. 2021. 
CHEN, I. J.; KITSIS, A. M. A research framework of sustainable supply chain management: The role of relational capabilities in driving performance. The International Journal of Logistics Management, v. 28, n.4, 2017.

CHEN, I. J.; PAULRAJ, A.; LADO, A. A. Strategic purchasing, supply management, and firm performance. Journal of Operations Management, v. 22, n. 5, p. 505-523, 2004.

CHIANG, C-Y.; KOCABASOGLU-HILLMER, C.; SURESH, N. An empirical investigation of the impact of strategic sourcing and flexibility on firm's supply chain agility. International Journal of Operations \& Production Management, v.32, n.01, 2012.

$\mathrm{CHO}$, D. W. et al. A framework for measuring the performance of service supply chain management. Computers and Industrial Engineering, v. 62, n. 3, p. 801-818, 2012.

CLAYTON, R. A. Purchasing: pipeline to corporate profit. In: 85th ANNUAL INTERNATIONAL CONFERENCE PROCEEDINGS. Anais...Phoenix. 2000.

CROXTON, K. L. et al. The supply chain management processes. The International Journal of Logistics Management, v. 12, n. 2, p. 13-36, 2001.

DAS, A.; NARASIMHAN, R. Purchasing competence and its relationship with manufacturing performance. Journal of Supply Chain Management, v. 36, n. 1, p. 17-28, 2000 .

FERDINAND, D. O melhor de Peter Drucker: a sociedade. São Paulo: Nobel, 2001.

ELLRAM, L. M.; BIROU, L. M. Purchasing for bottom line impact: improving the organization through strategic procurement. Irwin Professional Pub, 1995.

ELLRAM, L. M.; LIU, B. The financial Impact of supply management. Supply Chain Management Review, v. 6, n. 6, p. 30-37, 2002.

FAWCETT, S. E. et al. Supply chain information-sharing: benchmarking a proven path. Benchmarking: An International Journal, v.16, n.02, 2009.

FAWCETT, S. E. et al. Why supply chain collaboration fails: the socio-structural view of resistance to relational strategies. Supply Chain Management: An International Journal, v.20, n.06, 2015.

FILL, C.; VISSER, E. The outsourcing dilemma: a composite approach to the make or buy decision. Management decision, v. 38, n. 1, p. 43-50, 2000.

FOERSTL, K. et al. Cross-functional integration and functional coordination in purchasing and supply management: Antecedents and effects on purchasing and firm performance. International Journal of Operations and Production Management, v. 33, n. 6, p. 689-721. 2013.

FRANCISCO, L.L. Efeitos do planejamento de compras e das relações com fornecedores, no desempenho de empresas do ramo da metalurgia. 2017. Dissertação (Mestrado em Administração) - Faculdade de Ciências Empresariais. Disponível em: https://repositorio.fumec.br/xmlui/handle/123456789/234?show=full. Acesso em 17 jul 2017. 
FU, Q. The impact of alternative performance measures on portfolio procurement with contingent option contracts. International Journal of Production Economics, v. 167, p. 128-138, 2015.

HERNANDES, E. et al. Using GQM and TAM to evaluate StArt-a tool that supports Systematic Review. CLEI Electronic Journal, v. 15, n. 1, p. 3-3, 2012.

KIM, M.; SURESH, N. C.; KOCABASOGLU-HILLMER, C. A contextual analysis of the impact of strategic sourcing and E-procurement on performance. Journal of Business and Industrial Marketing, v. 30, n. 1, p. 1-16. 2015.

KPMG. The power of procurement. 2012. Disponível em: $<$ https://assets.kpmg.com/content/dam/kpmg/pdf/2012/07/the-power-of-procurement-aglobal-survey-of-procurement-functions.pdf>. Acesso em: 14 jun. 2018.

KRALJIC, P. Purchasing must become supply management. Harvard Business Review, v. 61, n. 5, p. 109-117, 1983.

KUMAR, R.; SINGH, R. K.; SHANKAR, R. Critical success factors for implementation of supply chain management in Indian small and medium enterprises and their impact on performance. IIMB Management review, v. 27, n. 2, p. 92-104, 2015.

LAI, K-H.; WONG, C. WY; LAM, J. S. L. Sharing environmental management information with supply chain partners and the performance contingencies on environmental munificence. International Journal of Production Economics, v. 164, p. 445-453, 2015.

LAMBERT, D. M. Supply chain management: processes, partnerships, performance. Supply Chain Management Inst, 2008.

LAMBERT, D. M.; COOPER, M. C. Issues in supply chain management. Industrial Marketing Management, v. 29, n. 1, p. 65-83, 2000.

LAMBERT, D. M.; ENZ, M. G. Issues in supply chain management: Progress and potential. Industrial Marketing Management, v. 62, p. 1-16, 2017.

MONDINI, L. C. et al. Impacto do planejamento de compras no desempenho financeiro da indústria de transformação do Brasil. REAd. Revista Eletrônica de Administração (Porto Alegre), v. 21, p. 113-140, 2015.

NOVACK, R. A.; SIMCO, S. W. The industrial procurement process: a supply chain perspective. Journal of Business Logistics, v. 12, n. 1, p. 145, 1991.

OKONGWU, U.; BRULHART, F.; MONCEF, B. Causal linkages between supply chain management practices and performance: A balanced scorecard strategy map perspective. Journal of Manufacturing Technology Management, v. 26, n. 5, p. 678$702,2015$.

OU, C. S. et al. A structural model of supply chain management on firm performance. International Journal of Operations and Production Management, v. 30 n. 5, p. 526-545, 2010.

PASQUALE, C. C. Strategic Sourcing. Revista Técnico-Científica da UNIESPFaculdade de São Paulo, v. 2, n. 8, 2012. 
PAULRAJ, A.; CHEN, I. J.; BLOME, C. Motives and performance outcomes of sustainable supply chain management practices: A multi-theoretical perspective. Journal of Business Ethics, v. 145, n. 2, p. 239-258, 2017.

PENG, J. et al. Mediation effect of business process and supply chain management capabilities on the impact of IT on firm performance: Evidence from Chinese firms. International Journal of Information Management, v. 36, n. 1, p. 89-96, 2016.

POHLEN, T. L.; LAMBERT, D. M. Supply chain metrics. S.A.M. Advanced Management Journal; Corpus Christi, v. 70, n. 2, p. 45-59, 2001.

POLliCE, F.; FLEURY, A. The link between Purchasing and Supply Management maturity models and the financial performance of international firms. Retrieved 201111-03. Disponível em: http://www. ifm. eng. cam. ac. uk/cim/symposium2010/proceedings/3_ pollice. pdf, 2011. Acesso em 14 jul 2017.

PRADABWONG, J. et al. Business process management and supply chain collaboration: effects on performance and competitiveness. Supply Chain Management, v. 22, n. 2, p. 107-121, 2017.

ROWLEY, J.; SLACK, F. Conducting a literature review. Management Research News, v. 27, n. 6, p. 31-39. 2004.

SARANGA, H.; MOSER, R. Performance evaluation of purchasing and supply management using value chain DEA approach. European Journal of Operational Research, v. 207, n. 1, p. 197-205, 2010.

SAUNDERS, M. N. K; ROJON, C. On the attributes of a critical literature review. Coaching: An International Journal of Theory, Research and Practice, v. 4, n. 2, p. 156-162, 2011.

SLACK, N. et al. Administração da produção. São Paulo: Atlas, 2009.

TALLURI, S.; NARASIMHAN, R. A methodology for strategic sourcing. European Journal of Operational Research, v. 154, n. 1, p. 236-250, 2004.

TORRACO, R. J. Writing integrative literature reviews: Using the past and present to explore the future. Human Resource Development Review, v. 15, n. 4, p. 404-428, 2016.

TRANFIELD, D.; DENYER, D.; SMART, P. Towards a methodology for developing evidence-informed management knowledge by means of systematic review. British Journal of Management, v. 14, n. 3, p. 207-222, 2003.

ÚBEDA, R.; ALSUA, C.; CARRASCO, N. Purchasing models and organizational performance: a study of key strategic tools. Journal of Business Research, v. 68, n. 2, p. 177-188, 2015.

VAN WEELE, A. J.; RIETVELD, G. Professional Development of Purchasing in Organisations: Towards a Purchasing Development Model. Global Purchasing \& Supply Chain Strategies-December 2000. 2000. Disponível em: http://www.gercorietveld.nl/wpcontent/uploads/2010/10/Purchasing-Development-Model.pdf. Acesso em 17 jul 2017.

VOM BROCKE, J. et al. Standing on the shoulders of giants: Challenges and recommendations of literature search in information systems research. Communications of the Association for Information Systems, v. 37, n. 1, p. 9, 2015. 
WELCH, J. A.; NAYAK, P. R. Strategic sourcing: a progressive approach to the make-orbuy decision. Academy of Management Perspectives, v. 6, n. 1, p. 23-31, 1992. 